\title{
TSPYL5 wt Allele
}

National Cancer Institute

\section{Source}

National Cancer Institute. TSPYL5 wt Allele. NCI Thesaurus. Code C158566.

Human TSPYL5 wild-type allele is located in the vicinity of 8q22.1 and is approximately 5 $\mathrm{kb}$ in length. This allele, which encodes testis-specific Y-encoded-like protein 5, is involved in inhibiting the deubiquitination of cellular tumor antigen p53 (TP53). 